DOI https://doi.org/10.18551/rjoas.2017-01.14

\title{
THE INFLUENCE OF ORGANIZATION CULTURE AND MOTIVATION ON THE VOLUNTEER'S INTENTION TO LEAVE MEDIATED BY THE WORK SATISFACTION: A STUDY ON VOLUNTEERS AT NON PROFIT ORGANIZATION SAVE STREET CHILD IN EAST JAVA PROVINCE
}

\author{
Widhiwasa Dinar ${ }^{\star}$, Armanu, Noermijati \\ Faculty of Economics and Business, University of Brawijaya, Indonesia \\ *E-mail: widhiwasa@ub.ac.id
}

\begin{abstract}
The purposes of this research are to analyze the influence of organization culture, motivation, and work satisfaction towards the volunteer's intention to leave, analyze the role of work satisfaction in mediating the influence of organization culture and motivation towards the volunteer's intention to leave in Save Street Child organization. This research uses quantitative approach by using purposive sampling method. Questionnaire is given to the volunteers of Save Street Child in East Java Province. There are 150 respondents in total. Data analysis technique uses Partial Least Square (PLS) as the analysis tool. This research results show that: (1) organization culture significantly influences the intention to leave, (2) organization culture significantly influences the work satisfaction, (3) motivation does not significantly influence the intention to leave, (4) motivation significantly influences the work satisfaction, (5) work satisfaction does not significantly influence the intention to leave, (6) Work satisfaction does not mediate the influence of organization culture on the intention to leave, (7) Work satisfaction does not mediate the influence of motivation on the intention to leave.
\end{abstract}

\section{KEY WORDS}

Volunteers, save street child organization, organization culture, intention to leave, motivation.

There are a lot of organizations, both public and private that need and use volunteer service to actualize their vision and mission. For example, the government in England makes program that supports volunteers by offering individuals who do not work full time or unemployed to become volunteer at Department of Health and Social Security. The purpose of this program is to facilitate individuals who do not work full time or unemployed to become volunteers in health or social service field. While in Canada, volunteers are empowered as an alternative resource to help improve the service quality at hospitals especially for non medical service, such as providing information to visitors, giving moral support, and calming down the patients (Handy and Srinivasan, 2004). Moreover, the involvements of the volunteers are also visible in charity or fund raise events, motivate people to be more prosperous and encourage them to be volunteers (Low et al., 2007).

The current issue here is that the demand of volunteer is often exceed the availability numbers of volunteers (Hager and Brudney, 2011). The research of Handy and Srinivasan (2004) found that the numbers of volunteers involved in non medical services, such as encouraging and motivating the patients, and various kinds of support services at hospitals in Canada in the last five years or more have decreased $80 \%$. In Scotland, the numbers of formal volunteers have decreased 5\% in 2005 and 6\% in 2006 (Volunteer Development Scotland Research Team, 2007). Labor Statistic Bureau in United States of America shows $2.2 \%$ degression of volunteer numbers from 2003 until 2005 (Salas, 2008). According to the research of United Parcel Service Foundation (1998), which was quoted from McCurley et al. (2007), there are several reasons that cause volunteers to leave organization. They found that poor management of volunteer, such as charity event that is not managed properly, does not use volunteer's time and talent appropriately, does not elaborate the volunteer's duties clearly, and no appreciation for volunteers, to cause individuals decision to stop being volunteer. 
To keep volunteers in organization, it needs a good management. David Smith's (1998) research found that $71 \%$ of volunteers stated that volunteers should be more organized. Friendly athmosphere of organization and experiences gained from the contribution given by the volunteers are important. By giving chances or opportunities for volunteers to express value and develop self identity, volunteers can help organization in forming organization culture which suits the volunteer's wish and need. According to Atkins and Turner (2006), unsatisfying culture that ignores the need of employees can cause disappointment in the employees and stimulate them to find opportunity in other place. In contrary, satisfying culture makes work environment enjoyable therefore increase work passion (Sadri and Lees, 2001). Beside organization culture, another variable that influences the work satisfaction of volunteers is motivation. Farrel et al. (1999) stated that interaction between motivation and real experience influences the satisfaction level of volunteers. If their main motivation is fulfilled through activities held by organization, then volunteers will be satisfied with their performance (Dorsch et al., 2002). By understanding the reason why individual becomes volunteer and what makes them stay, can give solution on how to motivate and maintain volunteer in order to actualize the purpose of the organization. The purpose of this research is to find out and analyze the influence of organization culture, motivation, and work satisfaction towards the volunteer's intention to leave at Save Street Child organization. The research problem are as follow: Is there any influences of organization culture towards volunteer's intention to leave at Save Street Child organization?; Is there any influences of organization culture towards volunteer's work satisfaction at Save Street Child organization?; Is there any influences of motivation towards volunteer's intention to leave at Save Street Child organization?; Is there any influences of motivation towards volunteer's work satisfaction at Save Street Child organization?; Is there any influences of work satisfaction towards volunteer's intention to leave at Save Street Child organization?; Does work satisfaction mediate the influence of organization culture towards volunteer's intention to leave at Save Street Child organization?; Does work satisfaction mediate the influence of motivation towards volunteer's intention to leave at Save Street Child organization?

\section{THEORETICAL FRAMEWORK AND HYPOTHESES}

Volunteers. According to Marx (1999), the meaning of volunteer is a person who helps other people without expecting any compensation and giving services without expecting reward. While according to Oppenheimer (2012), volunteer is individual that gives help without expecting something in return. Volunteer gives help in form of time, skills or services for organization, which is done without coercion. There are differences in the definition and conceptualization of volunteer's activity. Several researchers define volunteer's activity only as altruistic act and not paid. While other definitions include the possibility of self interest and need of acknowledgement (Barnes and Sharpe, 2009).

Non Profit Organization Culture. According to Schein (1984), organization culture is the basic pattern accepted by organization to act and solve problem, create employees who are able to adapt to environment and unite the members of the organization. Hofstede et al. (1990) defined culture as interactive aggregate of general characteristic that influence a group of people in responding their environment. While according to Susanto (2007), organization culture is values that become guidance for individual to respond external problem and adaptation into company so that each member of organization has to understand the existing values and how to act or behave. The opinion about organization culture generally emphasizes on the importance of values shared and bond of trust and also the influence towards the behavior of organization member.

Non profit organization has different characteristic from other organizations especially in organization values (Anheier, 2005). Moore (2000) added, various types of organization create values diversity. For profit organization value, it focuses more to the strategy to measure the stability of organization's financial stability, while non profit organization has values that are placed on social purpose achievement. In non profit organization, there is dominant value which is expected and suggested by organization to be shared to the 
members of organization. According to Anheier (2005) there are several dimensions that become the basic and value of non profit organization. They are: 1) Charity; 2) Philantropy; 3) Volunteering; 4) Giving.

It can be explained that there is a set of values, role and function of non profit organization that differentiate it from other organization. For example, governmental organization aims to optimalize social welfare of the whole community by distributing resources and providing unfulfilled basic needs. Private company aims to increase the profit of the company's owner by producing commodities that can be sold in market. While non profit organization aims to increase client's welfare (homeless, street children, homeless drifter, beggar, etc) and pay attention to minority's interest which is lack of attention from the government.

Motivation. Motivation is a process that has role in intensity, purpose and the continuity length of individual's effort to reach the target (Robbins, 2007). While according to Tua (2002), motivation is factors that direct and encourage people's behavior or desire to do an activity which is actualized in form of strong or weak effort. Maslow (1943) explained that individual's motivation can be illustrated in hierarchy form; that when one of the needs level is fulfilled, then that needs level can no longer able to motivate so that the next level of needs must be fulfilled immediately to motivate the individual.

To be able to understand the volunteer's motivation, Clary et al. (1998) used Functional Analysis method to comprehend the phenomenon and process in the dimension of behavior, social awareness, social relation, personality, and also the answer of question regarding the volunteer's motivation. Clary et al. (1998) formulized six indicators to measure volunteer's motivation, they are: 1) Understanding; 2) Values; 3) Social; 4) Career; 5) protective; 6) Enhancement.

Work Satisfaction. Work satisfaction has been defined and measured as global construction and as a concept with many dimensions (Locke, 1970; Price 1997; Scarpello and Campbell, 1983). In general, work satisfaction is defined as a function of acceptance relationship between what people wants from a job and what they accept as an offer (Locke, 1970). According to Mullin (2005), the level of work satisfaction is influenced by several factors such as: 1) Individual Factor; 2) Social Factor; 3) Cultural Factor; 4) Organisational Factor; and 5) Enviromental Factor. Several factors which are explained previously, only influence at certain condition and probably is not really influencing in other individual.

Intention to Leave. According to Zeffane (1994), intention to leave is employee's tendency or intention to leave their job (resign). Intention to leave is indicated as individual's attitude that refers to the evaluation result regarding the continuance of individual relation with organization and not yet materialized in an exact action form (Suwandi and Indriantoro, 1999). There are a lot of reasons that cause the occurrence of intention to leave; one of them is the desire to get a better job.

Research Models. This research model analyzes the influence of organization culture and motivation toward the intention to leave which is mediated by work satisfaction.

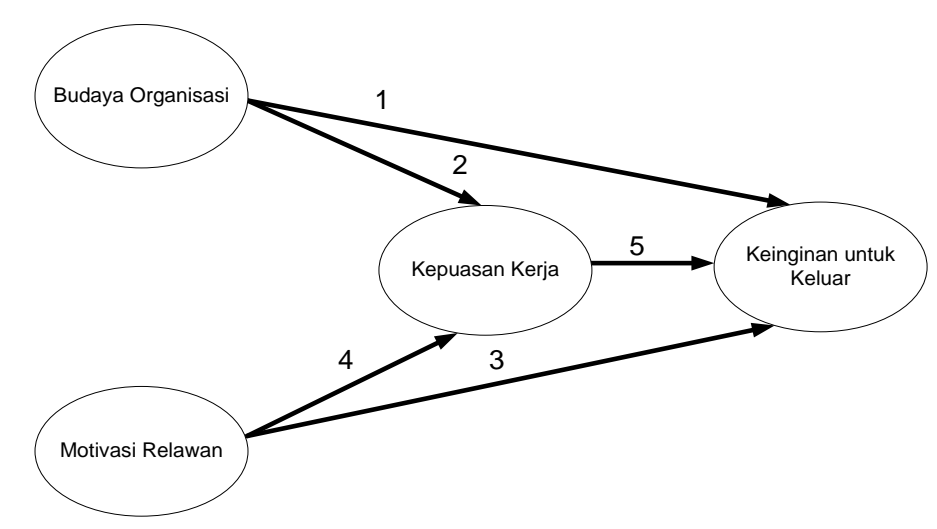

Figure 1 - Research Concept Framework 
Research Hypothesis. Based on the research conceptual framework, thus these are the hypothesis of the research:

H1: Organization culture significantly influences the intention to leave;

H2: Organization culture significantly influences the work satisfaction;

H3: Motivation significantly influences the intention to leave;

H4: Motivation significantly influences the work satisfaction;

H5: Work satisfaction significantly influences the intention to leave;

H6: Work satisfaction mediates the influence of organization culture on the intention to leave;

H7: Work satisfaction mediates the influence of motivation on the intention to leave.

\section{RESEARCH METHODS}

Population and Sample. Population in this research is the active volunteers at Save Street Child. The reason of choosing active volunteers at this organization as population is because they often involve in activities and they understand the characteristic of Save Street Child organization's culture. Sampling technique used in this research is purposive sampling. Questionnaire is distributed through What's App, BBM, LINE and e-mail containing link that is connected to Google form (electronic questionnaire) to volunteers of Save Street Child organization in Surabaya, Malang, Sidoarjo, Pasuruan, Mojokerto, Blitar, and Jember. The questionnaire's answer method is using 5 scale of Likert. Data analysis used is statistic technique PLS (Partial Least Square).

Table 1 - Variable Measurement

\begin{tabular}{|c|c|c|}
\hline No. & Variable & Indicator \\
\hline \multirow{5}{*}{1} & \multirow{5}{*}{$\begin{array}{l}\text { Organization Culture } \\
\text { (Cartwright, 1999) }\end{array}$} & Equity \\
\hline & & Equality \\
\hline & & Communication \\
\hline & & Empathy \\
\hline & & Technology \\
\hline \multirow{6}{*}{2} & \multirow{6}{*}{$\begin{array}{l}\text { Motivation } \\
\text { (Clarry et al., 1998) }\end{array}$} & Development \\
\hline & & Values \\
\hline & & Social \\
\hline & & Experience \\
\hline & & Protective \\
\hline & & Enhancement \\
\hline \multirow{5}{*}{3} & \multirow{5}{*}{ Work Satisfaction (Locke,1969) } & The work itself \\
\hline & & Appreciation \\
\hline & & Development opportunities \\
\hline & & Supervision \\
\hline & & Co-workers \\
\hline 4 & Intention to Leave & Intention to Leave \\
\hline
\end{tabular}

\section{DATA ANALYSIS AND DISCUSSION}

Description of Respondent. Respondent's characteristic is divided based on gender, age, education, and occupation. The number of female respondent is bigger than the male; there is $67 \%$ female and $33 \%$ male. Majority of the respondents which are $86 \%$ aged between $20-30$ years old, while the rest $13 \%$ and $1 \%$ aged below 20 years old and above 30 years old. Based on the education level, the number of respondents with bachelor degrees (S1) is the highest, which is $61 \%$, compared to the number of volunteers with Senior High School background, 26\%, D3 9\%, magister (S2) 3\%, and Junior High School 1\%. Meanwhile, the number of volunteers that is university students is the highest $63 \%$, compared to respondents who are private employees which is $13 \%$, and entrepreneur $12 \%$.

From the test result of convergent validity, it shows that all research indicators are valid in measuring each research variable, except Development and Enhancement indicator because they have loading factor value less than 0.5 .

The test of discriminant validity is done by comparing the root of average variance exstracted (AVE). 
Tabel 2 - The Test of Discriminant Validity

\begin{tabular}{|c|c|c|c|c|c|c|}
\hline \multirow[b]{2}{*}{ Variable } & \multirow[b]{2}{*}{ AVE } & \multirow[b]{2}{*}{$\begin{array}{l}\text { AVE } \\
\text { Root }\end{array}$} & \multicolumn{4}{|c|}{ Correlation between Latent Variable } \\
\hline & & & $\begin{array}{l}\text { Organization } \\
\text { Culture }\end{array}$ & Intention to Leave & Work Satisfaction & Motivation \\
\hline Organization Culture & 0.541 & 0.735 & 1.000 & - & - & - \\
\hline Intention to leave & 0.751 & 0.866 & -0.274 & 1.000 & - & - \\
\hline Work satisfaction & 0.531 & 0.809 & 0.498 & -0.245 & 1.000 & - \\
\hline Motivation & 0.528 & 0.726 & 0.403 & -0.261 & 0.714 & 1.000 \\
\hline
\end{tabular}

Source: Processed Data (2016).

Based on the test result of discriminant validity on Table 2, it is found out that AVE Root of every variable shows value $>0.5$ and close to 1 , therefore all variables have fulfilled discriminant validity.

Based on the test of composite reliability, it is found out the composite reliability value of each research variable: 1 ) organization culture $0.891 ; 2)$ motivation 0.898 ; 3) work satisfaction $0.910 ; 4)$ intention to leave 0.900 . The test result of Composite Reliability shows that each indicator mutually strengthens the latent variables or able to measure its own latent variable.

Table 3 - Structural Model Testing

\begin{tabular}{|l|l|}
\hline Variable & R Square \\
\hline Work satisfaction (Z) & 0.557 \\
\hline Intention to leave & 0.485 \\
\hline
\end{tabular}

Source: Processed Data (2016).

Based on the testing of inner model on table 2, it is found out that work satisfaction variable has influence with predictioned power of the whole model in the amount of 0.557 or $55.7 \%$. Intention to leave variable $(\mathrm{Y})$ has an influence with predictioned power of the whole model in the amount of 0.485 or $48.5 \%$. Moreover, the testing on inner model also can be seen from the evaluation of predicitve relevence stone-geiser $Q$-square test for predictive relevance. Next, $R$-square value is inserted in to $Q$-square equation as follow:

$Q^{2}=1-\left(1-R_{1}^{2}\right)\left(1-R_{2}^{2}\right) \ldots\left(1-R p^{2}\right)$

Based on the evaluation of $Q$-square, it shows that the model has predictive relevance, because it has value 0.7718 which is bigger than 0 (zero); it means the model is good to be used.

Result of Hypothesis Testing. The hypothesis testing result by using PLS and Sobel formula can be seen in Table 4.

Table 4 - Hypothesis Testing

\begin{tabular}{|l|l|l|l|l|}
\hline Variable Influence & $\begin{array}{l}\text { Original } \\
\text { Sample }(\mathrm{O})\end{array}$ & $\begin{array}{l}\mathrm{t} \text {-statistics } \\
(|\mathrm{O} / \mathrm{STDEV}|)\end{array}$ & t-tabel & Remarks \\
\hline Organization culture -> intention to leave & -0.192 & 2.006 & 1.64 & Significant \\
\hline Organization culture -> work satisfaction & 0.252 & 4.115 & 1.64 & Significant \\
\hline motivation -> intention to leave & -0.158 & 1.351 & 1.64 & Insignificant \\
\hline motivation -> work satisfaction & 0.613 & 11.709 & 1.64 & Significant \\
\hline work satisfaction -> intention to leave & -0.036 & 0.275 & 1.64 & Insignificant \\
\hline Organization culture -> intention to leave through work satisfaction & -0.0091 & -0.2645 & 1.64 & Insignificant \\
\hline Motivation -> intention to leave through work satisfaction & -0.0221 & -0.2717 & 1.64 & Insignificant \\
\hline
\end{tabular}

Source: Processed Data (2016).

The hypothesis testing is done by comparing $t$-statistic to $t$-table. If $t$-statistic value is bigger than t-tabel value (1.64), then it is decided that $\mathrm{Ho}$ is rejected and $\mathrm{Hi}$ is accepted or significant and in contrary, if t-statistic is smaller than t-table value (1.64), then it is decided that Ho is accepted and hi is rejected or insignificant. The analysis result of hypothesis test is 
presented as follows:

H1: There is a significant influence of organization culture on the intention to leave. The testing result of first hypothesis shows that the value of path coefficient for negative 0.912 , and value of t-statistic is 2.006 which is above t-table $1.64(5 \%)$, therefore $\mathrm{H} 1$ is accepted and interpreted that organization culture (X1) negatively and significantly influences the intention to leave $(\mathrm{Y})$.

H2: There is a significant influence of organization culture on work satisfaction. The testing result of second hypothesis shows that the value of path coefficient is positive 0.252 and value of $t$-statistic is 4.115 which is above t-tabel $1.64(5 \%)$, therefore $\mathrm{H} 2$ is accepted and interpreted that organization culture (X1) positively and significantly influences the work satisfaction $(Z)$.

H3: There is a significant influence of motivation on intention to leave. The testing result of third hypothesis shows that the value of path coefficient is negative 0.158 and value of t-statistic is 1.351 which is below t-table $1.64(5 \%)$, therefore $\mathrm{H} 3$ is rejected and interpreted that motivation (X2) does not significantly influence the volunteer's intention to leave $(Y)$.

H4: There is a significant influence of motivation on work satisfaction. The testing resut of fourth hypothesis shows that the value of path coefficient is positive 0.613 and value of $t-$ statistic is 11.709 which is above t-table $1.64(5 \%)$, therefore $\mathrm{H} 4$ is accepted and interpreted that motivation (X2) positively and significantly influences work satisfaction (Z).

H5: There is a significant influence of work satisfaction on intention to leave. The testing result of fifth hypothesis shows that the value of path coefficient is negative 0.036 and value of t-statistic is 0.275 which is below t-table $1.64(5 \%)$, therefore $\mathrm{H} 5$ is rejected and interpreted that work satisfaction $(Z)$ does not significantly influence volunteer's intention to leave $(Y)$.

H6: Work satisfaction mediates the influence of organization culture on the intention to leave. The testing of the sixth hypothesis used Sobel test. Based on testing result of Sobel for sixth hypothesis, value of path coefficient is negative 0.0091 and the value of t-statistic is -0.264 which is below $1.64(5 \%)$, therefore $\mathrm{H} 6$ is rejected and interpreted that work satisfaction does not mediate the influence of organization culture on the intention to leave.

H7: Work satisfaction mediates the influence of motivation on intention to leave. Based on Sobel test result for seventh hypothesis, the value of path coefficient is negative 0.0221 and value of t-statistic is -0.271 which is below $1.64(5 \%)$, therefore $\mathrm{H} 7$ is rejected. It is interpreted that work satisfaction does not mediate the influence of motivation on volunteer's intention to leave.

\section{DISCUSSION OF RESULTS}

The discussion of the research result is elaborated according to the descriptive analysis discussion of research variables and then hypothesis result discussion.

Organization Culture. Based on descriptive analysis of organization culture variable which is measured by 15 items, the average value of organization culture variable obtained is 3.830. It means that volunteers feel the strong organization culture at Save Street Child organization. Organization culture indicator which is perceived with the highest average value is technology indicator which has 4.187 for its average value, while organization culture with the lowest average value is equity indicator with 3.569 for its average value. The conclusion of descriptive analysis result is that technology does not only play important role in information tramission or decision making, but also as means to spread and internalize Save Street Child organization culture especially for the newly join volunteers. Meanwhile, equity indicator needs to be upgraded because it is related to the appreciation or experience obtained by the volunteers. Considering that volunteers work without being paid, therefore one of the ways to encourage their involvement is to give appreciation and valuable experience.

Organization culture has the influence on the intention to leave. From the testing result, first hypothesis proves that organization culture has significant influence on the intention to leave. This research result is in line with the researches of Mustika (2012), Johartono and 
Retnaningtyas (2013), and Malik (2014). According to Suwandi and Indriantoro (1999), intention to leave is influenced by several factors; one of them is organization culture. A strong culture forms a strong loyalty and commitment towards employees which impacts on the decreasing intention to leave the company. This research result finds that the stronger organization culture, the lessen volunteers' intention to leave Save Street Child and vice versa.

Organization culture has the influence on work satisfaction. The test of second hypothesis proves that organization culture significantly influences work satisfaction. This research result is in line with the research result of Sabri et al. (2011) and Lund (2003). According to Mullins (2005), the level of work satisfaction is influenced by several factors, such as culture factor (behavior, beliefs and value) and organization factor (structure, policy, procedure, leadership, technology, and work condition). This research result finds that the stronger organization culture, it can increase volunteer's work satisfaction, and vice versa.

Motivation. Based on descriptive analysis result of motivation variable which is measured by 19 items, the average value of motivation variable derived is 3.963. It means that the volunteers of Save Street Child have high motivation. Motivation indicator perceived to have the highest value is values indiciator with 4.402 for its average value, while motivation indicator with the lowest average value of 3.113 is the enhancement indicator. The conclusion of descriptive analysis result is that values have important role in motivating volunteers because the nature of values at Save Street Child organization is humanism and care for street children. Meanwhile, the enhancement indicator gets the lowest value because the reason of the individual becomes volunteer is not due to their willing to be acknowledged or famous, but it is due to their caring on other people especially street children.

Motivation has the influence on the intention to leave. The test of third hypothesis finds that motivation does not significantly influence the intention to leave. This research result is in contrary with the research result of Oliver (2012) and Sumarto (2009), but in line with the research of Mesch et al. (1998) which found that altruistic motivation within volunteers of Americorp does not influence the volunteer's retention. The research result shows that volunteer's motivation does not significantly influence the volunteer's intention to leave. The reason why motivation does not influence intention to leave is because when volunteers leave the organization, it is not because they want, but they have to. There are other conditions that force volunteers to leave the organizationn. Based on the respondents/volunteers' answers regarding intention to leave, it shows that the volunteer's intention to leave Save Street Child organization is low. It means that the volunteers joined this organization does not have the intention to leave this organization. Several reasons that force volunteers to leave organization are because they get a job (Wardell et al., 2000), they continue to study to higher level (Iveson, 1999; Blake and Jefferson, 1992), or they move to another area (Davis Smith, 1998). Furthermore, Locke et al. (2003) found that research which studies volunteer's motivation that is expected to be a determinant factor and also correlated with the continuation to become volunteers, shows evidence that it cannot be concluded. It is caused by the variability of research result regarding volunteer's motivation. Moreover, Locke et al. (2003) explained that what becomes the main motivation why people choose to be volunteers does not simply lead their continuity to be volunteers.

Motivation has the influence on work satisfaction. The test of fourth hypothesis finds that motivation significantly influences the work satisfaction. The result of this research is in line with the researches of Saleem et al. (2010), dan Srinadi dan Supartha (2015). In Rao's (2005) research, it is found that satisfaction in work acts as motivation in working. Motivation drives individual to work satisfaction. The result of this research finds that the increasing of volunteer's motivation significantly influences the increasing of volunteer's work satisfaction, and vice versa.

Work Satisfaction. Based on the descriptive analysis of work satisfaction variable, which is measured by 15 items, the average value of work satisfaction obtained is 3.589 . It means, volunteers at Save Street Child organization have high work satisfaction. Work satisfaction indicator perceived with the highest value is co-workers indicator with 3.858 
average value while work satisfaction indicator with the lowest average value of 3.349 is appreciation indicator. The conclusion of descriptive analysis result is that co-worker indicator plays important role in creating volunteer's work satisfaction. It is because when they become volunteers, individuals get opportunity to meet new colleagues. Moreover, the willingness of fellow volunteers to care and help each other in completing task or execute events gives satisfaction for volunteers. Meanwhile, appreciation indicator which has the lowest average value shows the lack of appreciation between volunteers and also from coordinator/General Coordinator regarding their contributions. This finding needs to be responded by increasing appreciation for every contribution they give both in form of energy and time by giving compliment or recognition.

Intention to Leave. Based on the descriptive analysis of intention to leave variable which is measured by 3 items, the average value of intention to leave variable obtained is 1.964. Based on Mean value, the intention of Save Street Child's volunteers to leave the organization shows a low number, it means volunteers feel comfort to keep contributing and involving in Save Street Child. As example, of three statement items asked to respondents, statement item D1.2 "if respondent is given choices, respondent will not choose to become volunteers" shows the lowest value 1.673. It means almost all respondents agree to still choose to become volunteers. Similarly, statement item D.1.1 "respondent already considers to leave their position as volunteers" and statement item D.1.3 "in the near future respondent will leave their position as volunteers" show low average values which are 2.127 and 2.093. It means the willingness of volunteers to stay in Save Street Child organization is high.

The influence of work satisfaction on intention to leave. The test result of fifth hypothesis finds that work satisfaction does not significantly influence the intention to leave. This research result is in contrary with the researches of Gregory (2011) and Puma (2012), but in line with the research of Sumarto (2009) which found that work satisfaction does not significantly influence the intention to leave. The more work satisfaction the employees get does not in line with the decreasing of intention to leave. The conclusion of this research is the increasing of volunteer's work satisfaction does not significantly influence the decreasing of volunteer's intention to leave and vice versa. The cause of uninfluential relation between work satisfaction and volunteer's intention to leave is because volunteer is the kind of job that is voluntary without any compensation and career stage. According to Ramlall (2003), the consideration of intention to leave is determined by compensation and career development factors. Compensation effectively forms psychology bound between individual and organization, and it is an indicator of individual's performance. Company can minimize the frequency of employees turnover with compensation, therefore company have to make sure that the employees are satisfied with the compensation they receive (Sumarto, 2009). In line with Sumarto's statement, Fiorillo's (2011) found that appreciation in form of compensation has influence towards volunteer's decision to donate their time and also increase their involvement in the organization. However, the nature of work at Save Street Child is voluntary without any compensation and guarantee of a better career stage, thus the satisfaction achieved by the volunteers is only temporary. Therefore, this makes volunteer's work satisfaction uninfluencial towards intention to leave.

Besides compensation factor, another cause that makes work satisfaction uninfluential towards intention to leave is because there is ambiguity related to volunteer's satisfaction (Locke et al., 2003). As example, in Finklestein's (1998) research, volunteer's work satisfaction is determined by the duration of volunteer's involvement study on AIDS organization. Moreover, according to Wardell et al. (2000), the dissatisfaction of volunteer towards their job as volunteer does not simply make it the reason they intend to leave. The cause that makes volunteers keep involving in voluntary activity eventhough they experience dissatisfaction is their responsibility towards organization or because there is no one to replace them to do the job. Volunteer's satisfaction or dissatisfaction in their voluntary work does not influence their intention to leave because the voluntary job at Save Street Child is not formally bound. Therefore volunteers are free to stay or leave the organization without any sanctions or punishments.

The role of work satisfaction in mediating the influence of organization culture on the 
intention to leave. In line with the fifth hypothesis, the sisxth hypothesis of this research is in contrary with the research result of Macintosh \& Doherty (2008). From this research result, the rejection of the sixth hypothesis shows that work satisfaction does not mediate the influence of organization culture on the intention to leave. The increasing of work satisfaction does not mediate the influence of organization culture and motivation towards the increasing or decreasing of volunteer's intention to leave. The work satisfaction that volunteers achieved through a strong organization culture and a high motivation does not influence volunteer's intention to leave because there is no strong bound with the organization. Whether volunteers are satisfied or not with the organization culture at Save Street Child, they tend to leave the organization because they need to get a better job or future guarantee, considering that the majority of the respondents are university or high school students.

The role of work satisfaction in mediating the influence of motivation on the intention to leave. In line with the fifth hypothesis, the seventh hypothesis of this research result is in contrary with the research result of Tzeng (2002). From this research result, the rejection of the seventh hypothesis shows that work satisfaction does not mediate the influence of motivation on the intention to leave. The increasing of work satisfaction does not mediate the influence of motivation on the increasing or decreasing of volunteer's intention to leave. The work satisfaction that the volunteers achieved through the high motivation does not influence the volunteer's intention to leave because the motivation that the volunteer's achieved is only a fulfillment of self actualization needs. Individual, in self actualization level, has needs to actualize the value and beliefs they have. Eventhough in Maslow Hierarchy self actualization need is the highest need, it does not mean that other needs are already fulfilled. This can be seen from the majority of Save Street Child's volunteers who are university or high school students that have not fulfilled their psychology and security need, such as a better occupation and future guarantee. Therefore they are most likely leaving the organization.

Based on the findings elaborated above, it can be concluded that factor influencing individual to become a volunteer is not the factor which is determining individual to keep being a volunteer. Although it can be identified that some variables influence the volunteer's desire to withstand, however the influence of volunteer's characteristic is very complex that it cannot predict what kind of characters that makes individual becomes long term volunteer (Locke et al., 2003). The research of Penner and Finklestein (1998) concluded that it cannot be determined whether satisfaction toward organization that cause the length of voluntary period of individual or the length of becoming volunteer that causes satisfaction. Therefore, for further research, a complex situation analysis that involved many factors regarding the intention of volunteer to leave needs to done.

\section{CONCLUSION AND SUGGESTIONS}

The researchers realize that this research has limitations of study, such as this research only measures the intention to leave from the volunteers' internal factor. Next researchers are expected to add volunteer's external factor such as decision to leave due to works, married plan, and continue to study to a higher level. Moreover, this research has not included open question item, thus it is expected that in the next research, researchers will include open question item to be able to examine more about the behavior and characteristic of volunteer.

Based on the research's results and discussion elaborated previously, it can be concluded that result of this research shows that organization culture significantly influences the intention to leave; organization culture significantly influences the work satisfaction; motivation does not significantly influence the intention to leave; motivation significantly influences the work satisfaction; work satisfaction does not significantly influence the intention to leave; work satisfaction does not mediate the influence of organization culture on the intention to leave; work satisfaction does not mediate the influence of motivation on the intention to leave.

Suggestions for further research:

Further research should expand the research object; not only on Save Street Child 
organization, but also other volunteer organizations such as Indonesia Mengajar, Kelas Inspirasi, Earth Hour, and Ketimbang Ngemis;

Further research should use qualitative method to get better understanding on the role of organization culture and motivation towards volunteer's intention to leave;

Further research should enrich the research field by adding untested variables in this research such as commitment, work stress, performance variables, and also the use of control variable (such as age range and gender) into research method.

\section{REFERENCES}

1. Anheier, H.K. 2005. Nonprofit Organizations: Theory Management Policy. London: Routledge.

2. Atkins, J.R. and Turner, D.S. 2006. Upgrade Stakeholder Service by Changing Your Agency's Organizational Culture. ITE Journal 76(12): 30.

3. Barnes, M.L. and Sharpe., E.K. 2009. Looking beyond Traditional Volunteer Management: A Case Study of an Alternative Approach to Volunteer Engagement in Parks and Recreation. Voluntas: International Journal of Voluntary and Nonprofit Organizations 20 (2): 169-87.

4. Blake, R, and Jefferson, S. 1992. Defection - Why? An Insight into the Reasons for Volunteers Leaving.

5. Clary, E.G., Snyder, M., Ridge, R.D., Copeland, J., Stukas, A.A., Haugen, J., and Miene, P. 1998. Understanding and Assessing the Motivations of Volunteers: A Functional Approach. Journal of Personality and Social Psychology 74 (6): 1516.

6. Dorsch, K., Reimer, H., Sluth, V., Paskevich, D., and Chelladurai, P. 2002. Volunteer Motivation: What Drives Sport Volunteer. International Year of Volunteers Research Program (Toronto: Canadian Centre for Philanthropy, 2002).

7. Fiorillo, D. 2011. Do Monetary Rewards Crowd out the Intrinsic Motivation of Volunteers? Annals of Public and Cooperative Economics 82 (2): 139-65.

8. Gregory, A.E. 2011. Transformational Leadership, Job Satisfaction, Organizational Commitment and Non-Supervisory Nurses' Intention to Leave. Lynn University.

9. Gunawardena, C.N., Linder-VanBerschot, J.A., LaPointe, D.K., and Rao, L. 2010. Predictors of Learner Satisfaction and Transfer of Learning in a Corporate Online Education Program. The Amer. Jrnl. of Distance Education 24 (4): 207-26.

10. Hager, M.A. and Brudney, J.L. 2011. Problems Recruiting Volunteers: Nature versus Nurture. Nonprofit Management and Leadership 22 (2): 137-57.

11. Handy, F. and Srinivasan, N. 2004. Valuing Volunteers: An Economic Evaluation of Net Benefits of Hospital Volunteers. Nonprofit and Voluntary Sector Quarterly 33(1): 28-54.

12. Hofstede, G. et al 1990. Measuring Organizational Cultures: A Qualitative and Quantitative Study across Twenty Cases. Administrative Science Quarterly, 286-316.

13. Iveson, C. 1999. Recruitment and Retention of Volunteers. University of Manchester.

14. Johartono, J. and Retnaningtyas, W. 2014. Analisa Pengarush Stres Kerja, Kepuasan Kerja, Budaya Organisasi, dan Komitmen Organisasi terhadap Turnover Intention Karyawan Kantor Konsultan Pajak di Surabaya. Tax \& Accounting Review 3 (2): 162.

15. Locke, E.A. 1970. Job Satisfaction and Job Performance: A Theoretical Analysis. Organizational Behavior and Human Performance 5 (5): 484-500.

16. Locke, M., Ellis, A., Smith, J.D. 2003. Hold on to What You've Got: The Volunteer Retention Literature. Voluntary Action 5 (3): 81-99.

17. Low, N., Butt, S., Ellis, P., Smith, J.D. 2007. Helping Out: A National Survey of Volunteering and Charitable Giving. http://openaccess.city.ac.uk/2547/.

18. Lund, D.B. 2003. Organizational Culture and Job Satisfaction. Journal of Business \& Industrial Marketing 18 (3): 219-36.

19. Macintosh, E.W. and Doherty, A. 2010. The Influence of Organizational Culture on Job Satisfaction and Intention to Leave. Sport Management Review 13 (2): 106-17.

20. Malik, A. 2014. Pengaruh Budaya Organisasi aan Loyalitas Kerja Dengan Intensi Turnover pada Karyawan PT. Cipaganti Heavy Equipment Samarinda. 
21. Marx, J.D. 1999. Motivational Characteristics Associated with Health and Human Service Volunteers. Administration in Social Work 23 (1): 51-66.

22. Maslow, A.H. 1943. A Theory of Human Motivation. Psychological Review 50 (4): 370.

23. McCurley, S., Lynch, R., Training, J. 2007. Keeping Volunteers: A Guide to Retention. Directory of Social Change.

24. Mesch, D., Tschirhart, M., Perry, J., Lee, G. 1998. Altruists or Egoists? Retention in Stipended Service'. Non-profit Management and Leadership, 9: 3-21.

25. Mullins, L.J. 2005. Management and Organisational Behaviour. 7th edition. Prentice Hall.

26. Mustika, I.K. 2012. Analisis Budaya Organisasi Dan Kepuasan Kerja Melalui Komitmen Pengaruhnya Terhadap Intent to Leave Karyawan Pada Industri Jasa Perhotelan Di Kabupaten Badung Dan Kota Denpasar. Jurnal Mitra Ekonomi Dan Manajemen Bisnis 3(1): 1-24.

27. Oliver, K. 2012. An Examination of the Relationships between Autonomous Motivation and Situational Constraints with Job Attitudes, Intention to Leave, and General Stress.

28. Oppenheimer, M. 2012. Volunteering: Why We Can't Survive without It. UNSW Press.

29. Penner, L.A. and Finkelstein, M.A. 1998. Dispositional and Structural Determinants of Volunteerism. Journal of Personality and Social Psychology 74 (2): 525.

30. Price, J.L. 1997. Handbook of Organizational Measurement. International Journal of Manpower 18 (4/5/6): 305-558.

31. Ramlall, S. 2003. Organizational Application Managing Employee Retention as a Strategy for Increasing Organizational Competitiveness. AHRM Research 8 (2): 63-72.

32. Sabri, P.S., Ilyas, M., Amjad, Z. 2011. Organizational Culture and Its Impact on the Job Satisfaction of the University Teachers of Lahore. International Journal of Business and Social Science 2 (24): 121-28.

33. Sadri, G. and Lees, B. 2001. Developing Corporate Culture as a Competitive Advantage. Journal of Management Development 20 (10): 853-59.

34. Salas, G.R. 2008. Volunteer Functions, Satisfaction, Commitment, and Intention to Leave Government Volunteering. Lynn University.

35. Saleem, R., Mahmood, A., Mahmood, A. 2010. Effect of Work Motivation on Job Satisfaction in Mobile Telecommunication Service Organizations of Pakistan. International Journal of Business and Management 5 (11): p213.

36. Scarpello, V. and Campbell, J.P. 1983. Job Satisfaction and the Fit between Individual Needs and Organizational Rewards. Journal of Occupational Psychology 56 (4): 315-28.

37. Schein, E.H. 1984. Coming to a New Awareness of Organizational Culture. Sloan Management Review 25 (2): 3-16.

38. Smith, J.D. 1998. The 1997 National Survey of Volunteering. National Centre for Volunteering: London.

39. Srinadi, N.N. et al 2015. Peran Mediasi Kepuasan Kerja pada Hubungan Motivasi Kerja dengan Intention To Quit. E-Jurnal Ekonomi Dan Bisnis Universitas Udayana 4 (03).

40. Sumarto. 2009. "Meningkatkan Kompensasi, Kepuasan Kerja Dan Motivasi Untuk Mengurangi Labor Turnover Intention." Jurnal Riset Ekonomi \& Bisnis 9 (1): 45.

41. Susanto. 2007. Manajemen Perilaku Organisasi. Jakarta: Prenada Media.

42. Suwandi, H. et al 1999. Pengujian Model Turnover Pasewark Dan Strawser: Studi Empiris Pada Lingkungan Akuntansi Publik. Jurnal Riset Akuntansi Indonesia 2: 173-95.

43. Tua, E.H.M. 2002. Manajemen Sumber Daya Manusia. Penerbit PT Gramedia Widia Sarana Indonesia, Jakarta.

44. Tzeng, H-M. 2002. The Influence of Nurses' Working Motivation and Job Satisfaction on Intention to Quit: An Empirical Investigation in Taiwan. International Journal of Nursing Studies 39 (8): 867-78.

45. Volunteer Development Scotland Research Team. 2007. Annual Statistics on Volunteering 2007 (Survey November 2006). Volunteer Development Scotland: Stirling.

46. Wardell, F.L. and Whalley, L. 2000. Volunteers: Making a Difference.

47. Zeffane, R.M. 1994. Understanding Employee Turnover: The Need for a Contingency Approach. International Journal of Manpower 15 (9): 22-37. 